Tradisi Pesantren : Antara Tradisionalis dan Modernis

\title{
Tradisi Pesantren : Antara Tradisionalis Dan Modernis (Studi Kasus Implikasi Kepemimpinan Kiai Pesantren Di Sumatera Selatan)
}

\author{
Salni Fajar \\ Kementrian Agama Kabupaten Banyuasin \\ Salnifajar123@gmail.com
}

\begin{abstract}
Abstrak
Hasil penelitian ini menunjukan teori kepemimpinan yang dikemukakan oleh Max Weber dan tipe kepemimpinan dalam suatu organisasi pendidikan yaitu Weber yang membagi pola kepemimpinan berdasarkan dengan teori dominasinya menjadi tiga, yaitu kepemimpinan tradisional, karismatik, dan rasional. Ternyata dalam prakteknya kepemimpinan kiai di pesantren mempunyai peran yang sangat penting untuk memajukan dunia pendidikan di pesantren. Tetapi yang tidak kalah penting juga yaitu latar belakang pendidikan kiai dan lingkungan dimana tempat besarnya kiai tersebut. Tipe kepemimpinan kiai di Pondok Pesantren Nurul Islam oleh kiai Syazali menggunakan tipe kepemimpinan karismatik tradisionalis dan dalam saat-saat tertentu menggunakan pola otokratis dan demokratis, dalam kurikulum sudah mengkombinasi antara salafiyah dan modern, terlihat dari masuknya beberapa kurikulum pemerintah, baik dari Dinas Pendidikan maupun Kementerian Agama. Sedangkan tipe kepemimpinan yang diterapkan oleh kiai Tol'at adalah tipe kepemimpinan rasional modernis, dan pada saat-saat tertentu juga pola intruktif dan koordinatif di digunakan oleh kiai Tol'at dan berpolitik praktis. Sehingga berimplikasi pada aktifitas pesantren baik menyangkut kaderisasi kepemimpinan, sistem pembelajaran, sistem nilai dan jaringan kiai dalam masyarakat, sampai pada kiai berpolitk praktis. Ini semakin menarik untuk mendalami lebih lanjut disertasi ini, sehingga nampak betul tradisi-tradisi melayu yang ada di Sumatera Selatan.
\end{abstract}

Kata kunci : Karismatik, Tradisionalis dan Rasional Modernis

\begin{abstract}
The results of this study show leadership theory proposed by Max Weber and the type of leadership in an educational organization namely Weber which divides leadership patterns based on their dominance theory into three, namely traditional, charismatic, and rational leadership. It turns out that in practice the leadership of the kiai in pesantren has a very important role to advance the world of education in boarding schools. But what is also important is the educational
\end{abstract}


background of the clerics and the environment where the kiai is. The type of kiai leadership in Islamic Boarding School Nurul Islam by kiai Syazali uses a type of traditionalist charismatic leadership and in certain moments uses an autocratic and democratic pattern, in the curriculum it has combined between salafiyah and modern, it can be seen from the inclusion of several government curricula, both from the Education Office and the Ministry Religion. Whereas the type of leadership applied by the cleric Tol'at is a type of modernist rational leadership, and at certain times intructive and coordinative patterns are used by scholars and practicing politics. So that it has implications for the activities of the pesantren both concerning the regeneration of leadership, the learning system, the value system and the network of kiai in society, to the kiai with practical politics. It is increasingly interesting to explore this dissertation further, so that the Malay traditions in South Sumatra appear to be correct.

\section{Keywords : Charismatic, Traditionalist and Modernist Rationality}

\section{Pendahuluan}

Pesantren dengan aktifitas yang ada di dalamnya mampu memberikan keunikan dan warna pendidikan tersendiri tidak terkecuali di dunia melayu, keunikan ini nampak dari tradisi pembelajaran yang ada di dalamnya, mulai dari sistem pembelajaran yang berbeda dengan pendidikan pada umumnya, termasuk materi-materi yang diajarkan pada masa awal keberadaanya (Abbudin Nata, 2001 : 100). Menurut Abdurrahman Wahid (Wahid, 2001: 171), Seiring kemanfaatan yang dirasakan, akhirnya pemburu ilmu agama itupun semakin bertambah dan bertambah. Kondisi inilah yang kemudian menuntut adanya komponen lain (selain kiai dan santri), yakni masjid, tempat tinggal (asrama atau pondokan) dan kitab yang diajarkan (Martin van Bruinessen, 1999 : 17).

Lembaga pendidikan Islam disebut pesantren apabila memiliki tokoh sentral yang disebut kiai. Istilah kiai bukan berasal dari bahasa Arab, melainkan dari bahasa Jawa (Ziemek, 1986: 130). Dhofier mengatakan, kata 'kiai' dipakai untuk tiga jenis gelar yang berbeda, yaitu: pertama, sebagai gelar kehormatan bagi barang-barang yang dianggap sakral, seperti "kiai garuda kencana", kereta emas yang ada di Kraton Yogyakarta; kedua, gelar kehormatan bagi orang-orang tua pada umumnya; ketiga, gelar yang diberikan oleh masyarakat kepada ahli agama Islam yang memiliki pesantren dan mengajar kitab-kitab Islam klasik kepada para santrinya (Ziemek, 1986: 55). Hasbullah mengemukakan, peran penting kiai dalam pendirian, pertumbuhan, perkembangan, dan pembinaan pesantren merupakan unsur yang paling esensial (Hasbullah, 1999: 144). Keberhasilan pesantren banyak bergantung pada keahlian dan kedalaman ilmu, wibawa, serta keterampilan kiai. Dalam konteks ini, kepemimpinan kiai sangat menentukan 
masa depan pesantren. Kiai di pesantren adalah penggerak dalam mengemban dan mengembangkan pesantren sesuai dengan pola yang dikehendakinya, karena di tangan seorang kiai, pesantren tetap eksis sampai saat ini. Oleh sebab itu, kiai dan pesantren merupakan dua sisi yang selalu berhubungan erat secara dinamis. Sebagai pemimpin di pesantren, kebijakan-kebijakan kiai sangat berpengaruh terhadap sistem, arah, visi, dan misi pesantren, lebih-lebih kiai yang memiliki kemampuan kepemimpinan yang amat disegani oleh para santri, alumni, simpatisan dan masyarakat luas, sehingga dapat dipastikan kiai yang demikian memiliki garis komando yang kuat dan ditaati oleh bawahannya.

Kiai sebagai pemimpin yang karismatik dan rasional menjadi hal yang menarik di kalangan pemerhati sosial dan para pemikir Islam serta pendidikan Islam, seperti pendapat Abdurrahman Wahid yang mengatakan, bahwa munculnya kiai karismatik berawal dari penerimaan masyarakat dan warga pesantrennya secara mutlak (Wahid, 1978). Kiai pada umumnya adalah sosok yang diterima oleh warga pesantren dan di luar pesantren, bahkan perkataan dan perbuatannya kadang menjadi fatwa bagi seluruh warga pesantren dan masyarakat luas atas segala sesuatu yang membutuhkan ketegasan hukum (Islam).

Di Sumatera Selatan ada 321 pondok pesantren umum dan 31 pondok pesantren salafiyah murni (Data Kantor Wilayah Kementerian Agama Provinsi Sumatera Selatan tahun 2017), dari sekian banyak pesantren tersebut ada dua Pondok Pesantren yang menurut usia berdiri dan cikal bakalnya sudah tua yaitu Pesantren Nurul Islam Seribandung Ogan Ilir (1932) dan Pesantren Raudhatul Ulum Sakatiga Ogan Ilir (1930), masing-masing pesantren ini mengalami pasang surut dalam perkembangannya dan tipe kepemimpinan kiai dalam lembaga pendidikan ini menarik untuk di teliti, sebab sekalipun Nurul Islam menggunakan sistem pendidikan salaf/tradisional, sejauh ini pesantren dianggap mampu merespons segala perkembangan zaman yang terjadi. Ini ditandai dengan tetap stabilnya jumlah santri yang menempuh pendidikan di pesantren Nurul Islam Seribandung (Dokumen Pesantren Nurul Islam Seribandung tahun pelajaran 2016/2017). Dan Pesantren Raudhatul Ulum sudah mentransforfasi diri ke arah modernis.

Peneliti sengaja mengambil obyek penelitian tentang kepemimpinan kiai Pesantren Nurul Islam Seribandung dan Pesantren Raudhatul Ulum Sakatiga dalam implementasinya tradisionalis/salafiyah dan modernis, karena kiai memiliki pengaruh serta kharisma yang kuat, khususnya bagi masyarakat Kabupaten Ogan Ilir Sumatera Selatan dalam menjaga tradisi salafiyah syafi'iyah dan tradisi modern. Selain sebagai penjaga tradisi salaf, pengasuh Pondok Pesantren Nurul Islam menjadi tumpuan seluruh masyarakat karena sikap netralitasnya terhadap partai politik saat ini (wawancara dengan kiai Syazali (mudir) anak kiai Anwar, pada tanggal 12 April 2018). Di lain hal pondok pesantren Raudhatul yang 
berafiliasi dengan Partai Politik. Dengan sikap ini pengasuh hanya memfokuskan diri pada pemberdayakan umat melalui pendidikan di Pondok Pesantren dan berbagi dalam berdakwah (Wawancara dengan Kiai Tol'at tanggal 14 April 2018). Karena itulah kiai kedua Pesantren ini menjadi figur leader khususnya bagi para santri-santrinya dalam menjalankan roda kepemimpinan di Pondok Pesantren dengan kelebihan dan kekurangannya.

Pesantren Nurul Islam Seribandung dan Raudhatul Ulum ditetapkan sebagai objek penelitian karena memiliki tipe pesantren tradisional dan modern yang memiliki visi yang luhur, yakni mempertahankan ajaran Ahl al-Sunnah Wa al-Jamaah yang dikemas dalam sistem pembelajaran kitab-kitab kuning dan penguatan bahasa Arab sebagai acuan utama dalam referensi materi pembelajaran dan pengembangannya pada kurikulum yang bersifat umum. Hal ini terkait dengan landasan berpikir pengasuh kedua Pondok Pesantren tersebut yang perlu untuk diketahui dalam penelitian ini, karena landasan berpikir pengasuh mempengaruhi sistem yang diterapkan dalam pendidikan di pesantren. Kiai di pondok pesantren masing-masing memiliki tipe kepemimpinan yang berbeda serta memiliki kesamaan dalam memimpin pondok pesantren, terutama bila dihadapkan dengan kondisi globalisasi saat ini (Muhaimin, 2004: 24). Kiai dari masingmasing pondok pesantren memiliki karakter kepemimpinan, baik visi, misi, maupun paradigma dalam mempertahankan sistem pendidikan salaf.

\section{Kerangka teori}

Teori yang dipakai dalam penelitian yaitu teori kepemimpinan Max Weber dan tipe kepemimpinan dalam suatu organisasi pendidikan. Weber yang membagi tipe kepemimpinan berdasarkan dengan teori dominasinya menjadi tiga, yaitu kepemimpinan tradisional, karismatik, dan rasional (Bryan S. Turner, 1974:23) menjelaskan teori Weber ini, bahwa kepemimpinan karismatik di sini adalah diangkat berdasarkan atas suatu kepercayaan bahwa pemimpin itu dapat memberikan berkah karena tuah/mantranya, keselamatan untuk melindungi rakyat, karena dianggap memiliki ilmu gaib. kepemimpinan semacam ini tidak hanya terdapat dalam masyarakat yang primitif, tetapi justru pada masyarakat modernpun masih terdapat kepercayaan akan adanya pemimpin-pemimpin yang dianggap mempunyai karisma itu.

Pemimpin tradisional adalah pemimpin yang dipilih atas dasar kebiasaan turun temurun/tradisi. Misalnya pada zaman feodal kedudukan: raja, bupati bahkan lurah di desa pun orang cenderung memilih turunan atau sanak famili dari pejabat lama. Sistem ini tidak memperhitungkan kecakapan calon pemimpin, yang terpenting adalah melestarikan tradisi, dan pada umumnya rakyat begitu yakinnya akan kebaikan tradisi yang dianut. Melanggar tradisi berarti melanggar 
adat, sehingga jarang sekali rakyat biasa berani melanggar kebiasaan itu (Kartono, 1994: 27).

Sedangkan pemimpin rasional yaitu pemimpin diangkat didasarkan atas landasan kecakapan, pengalaman, atau pendidikan dari yang bersangkutan dan legal, karena juga berlandaskan hukum atau peraturan yang berlaku. Dengan demikian dapat terjadi, seorang yang diangkat jadi pemimpin karena ditunjuk atau ditetapkan dari atas, dengan adanya pertimbangan-pertimbangan tersebut tadi yaitu kecakapan, pengalaman, pendidikan, jasa-jasa, pertimbangan politis dan sebagainya.

Teori kepemimpinan modern, menurut (Sudaryono, 2014 : 163) Kepemimpinan modern tidak hanya bekerja sendiri, tetapi juga melibatkan pengikut atau orang yang dipimpinnya. Dalam proses ini melibatkan niat dan keinginan. Pemimpin dan pengikut yang terlibat aktif, sehingga tercapai tujuan yang sama.

Tipe Kepemimpinan karismatik tradisionalis adalah pemimpin yang dapat dipercaya oleh orang banyak dan mempunyai wibawa serta pengikut yang sami'na wa 'atho'na dan penerapan lingkungan kerja bawahannya dengan cara pembelajaran secara kebetulan/insidentil serta garis keturunan pemimpin sebelumnya menjadi prioritas untuk mengelola organisasi. Menurut House (1977), Indikator kepemimpinan karismatik yaitu, pemimpin yang memiliki pengaruh yang dalam bagi pengikut. Pertama, para pengikut merasa bahwa setiap perintah pemimpin adalah benar, kedua, mereka bersedia mematuhi pemimpin (sam'an wa to'atan), ketiga, mereka merasakan kasih sayang dan perhatian dari pemimpin, keempat, secara emosional mereka terlibat dalam misi kelompok atau organisasi, kelima, mereka memiliki keinginan bekerja dengan tinggi, dan keenam, pemimpin selalu yakin bahwa mereka dapat berkontribusi terhadap keberhasilan dari misi organisasi.

Sedangkan tipe kepemimpinan rasional modernis adalah pemimpin yang diangkat berdasarkan kesempatan dan kemampuan serta mampu menggerakan segenap bawahannya sesuai dengan Peraturan Organisasi (PO) modern yang diinginkan oleh pemimpin. Adapun indikator kepemimpinan rasional menurut Ahmad Sudrajat dalam Artikel Pendidikan terbit tanggal 2 Januari 2008 adalah memiliki kemampuan untuk memimpin dan keinginan bagi banyak orang, setiap kebijakan tidak bertentangan dengan need bawahan yang dipimpinannya, visioner selalu menatap masa depan yang lebih baik, mempunyai nilai demoktarisasi yang baik, mampu mengendalikan setiap struktur yang telah disusun dan yang telah disepakati bersama, memperluas jaringan (network) ke semua lembaga dan individu, memiliki motivasi yang kuat terhadap segala perubahan yang terjadi baik di internal organisasi maupun ekternal, mau belajar di saat mengalami kegagalan atau suatu tekanan yang hebat. 
Selanjutnya dalam penelitian ini peneliti akan melihat implikasi dari tipe kepemimpinan yang di terapkan oleh kiai pesantren. Dalam teori dan pengertian impikasi Menurut (Islamy 2003, 114-115), implikasi adalah segala sesuatu yang telah dihasilkan dengan adanya proses perumusan kebijakan. Dengan kata lain implikasi adalah akibat-akibat dan konsekuensi-konsekuensi yang ditimbulkan dengan dilaksanakannya kebijakan atau kegiatan tertentu.

Menurut (Winarno 2002:171-174): Setidaknya ada lima dimensi yang harus dibahas dalam memperhitungkan implikasi dari sebuah kebijakan. Dimensidimensi tersebut meliputi: pertama, implikasi kebijakan pada masalah-masalah publik dan implikasi kebijakan pada orang-orang yang terlibat. Kedua, kebijakan mungkin mempunyai implikasi pada keadaan-keadaan atau kelompok-kelompok diluar sasaran atau tujuan kebijakan. Ketiga, kebijakan mungkin akan mempunyai implikasi pada keadaan-keadaan sekarang dan yang akan datang. Keempat, evaluasi juga menyangkut unsur yang lain yakni biaya langsung yang dikeluarkan untuk membiayai program-program kebijakan publik. Kelima, biaya-biaya tidak langsung yang ditanggung oleh masyarakat atau beberapa anggota masyarakat akibat adanya kebijakan publik.

Menurut (Silalahi, 2005: 43), implikasi adalah akibat yang ditimbulkan dari adanya penerapan suatu program atau kebijakan, yang dapat bersifat baik atau tidak terhadap pihak-pihak yang menjadi sasaran pelaksanaan program atau kebijaksanaan tersebut. Berdasarkan beberapa pendapat di atas maka yang dimaksud dengan implikasi dalam penelitian ini adalah suatu akibat yang terjadi atau ditimbulkan pelaksanaan kebijakan oleh kepemimpinan kiai pesantren atau program tertentu bagi sasaran pelaksanaan program baik yang bersifat umum maupun pribadi untuk keberlangsungan pengembangan pesantren.

Dalam penelitian ini peneliti fokus pada kepemimpinan kiai yang dapat memberikan implikasi langsung pada pesantren yang dipimpinnya, karena kepemimpinan kiai pada setiap pesantren mempunyai tipe kepemimpinan yang berbeda-beda dengan demikian menurut (Sina, 2012: 24) "kiai sebagai agent of change dalam setiap konstalasi perubahan sosial", artinya kiai eksis dengan pesantren untuk menyuarakan progress kehidupan ke arah yang lebih baik. Dalam hal ini kepemimpinan kiai di dua pesantren yaitu pesantren Nurul Islam Seribandung dan pesantren Raudhatul Ulum Sakatiga. Dan teori kepemimpinan kiai ini akan banyak diungkapkan pada bab kedua dalam disertasi ini, sehingga dapat memberikan penjelasan yang utuh tentang kepemimpinan kiai di pesantren dari sudut pandang para pakar yang berbeda.

\section{Tradisi dan Pondok Pesantren}

Tradisi pesantren adalah segala sesuatu yang dibiasakan, dipahami, dihayati, dan dipraktikan di pesantren, yaitu berupa nilai-nilai dan 
implementasinya dalam kehidupan sehari-hari, sehingga membentuk kebudayaan dan peradaban yang membedakannya dengan tradisi yang terdapat pada lembaga pendidikan lainnya. Tradisi yang dimaksud adalah, (1) Tradisi Rihlah Ilmiah, (2) Tradisi Menulis Buku, (3) Tradisi Meneliti, (4) Tradisi Membaca Kitab Kuning, (5) Tradisi Berbahasa Arab, (6) Tradisi Mengamalkan Thariqat, (7) Tradisi Menghafal, (8) Tradisi Berpolitik (Abudin Nata, 2012 : 314).

Dhofier mendefinisikan bahwa pesantren adalah lembaga pendidikan tradisional Islam untuk mempelajari, memahami, menghayati dan mengamalkan ajaran Islam dengan menekankan pentingnya moral keagamaan sebagai pedoman perilaku sehari-hari (Dhofier, 1987: 84). Nasir mendefinisikan bahwa pesantren adalah lembaga keagamaan yang memberikan pendidikan dan pengajaran serta mengembangkan dan menyebarkan ilmu agama Islam (Nasir, 2005: 80). Team penulis Departemen Agama dalam buku Pola Pembelajaran Pesantren mendefinisikan bahwa pesantren adalah pendidikan dan pengajaran Islam di mana di dalamnya terjadi interaksi antara kiai dan ustdaz sebagai guru dan para santri sebagai murid dengan mengambil tempat di masjid atau di halaman-halaman asrama (pondok) untuk mengkaji dan membahas buku-buku teks keagamaan karya ulama masa lalu. Dengan demikian, unsur terpenting bagi pesantren adalah adanya kiai, para santri, masjid, tempat tinggal (pondok) serta buku-buku (kitab kuning) (Depag, 2003: 3). Rabithah Ma'ahid Islamiyah (RMI) mendefinisikan pesantren sebagai lembaga tafaqquh fi al-din yang mengemban misi meneruskan risalah Nabi Muhammad SAW, sekaligus melestarikan ajaran Islam yang berhaluan Ahlu al-sunnah wa al- Jama'ah 'ala al-Tariqah al-Mazahib al'Arba'ah.

Mastuhu mendefinisikan bahwa pesantren adalah lembaga tradisional Islam untuk memahami, menghayati dan mengamalkan ajaran agama Islam (tafaqquh fi al-din) dengan menekankan pentingnya moral agama Islam sebagai pedoman hidup bermasyarakat sehari-hari (Mastuhu, 1994: 4).

Dari berbagai pengertian yang telah dikemukakan, maka dapat dipahami bahwa pesantren adalah lembaga pendidikan Islam tradisional yang mempelajari ilmu agama (tafaqquh fi al-din) dengan penekanan pada pembentukan moral santri agar bisa mengamalkannya dengan bimbingan kiai dan menjadikan kitab kuning sebagai sumber primer serta masjid sebagai pusat kegiatan.

\section{Pesantren Tradisional dan Modern}

Dalam rangka memperjelas penelitian ini penulis menyajikan beberapa indikator pesantren tradisional dan modern, menurut Dhofier (2011: 65), pesantren tradisional/salafiyah adalah lembaga pesantren yang mempertahankan pengajaran kitab-kitab Islam klasik (salaf) sebagai inti pendidikan. Sistem madrasah ditetapkan hanya untuk memudahkan sistem sorogan yang dipakai 
dalam lembaga-lembaga pengajian bentuk lama, tanpa mengenalkan pengajaran pengetahuan umum.

Perbedaan mencolok antara pesantren tradisional dengan modern adalah pada panggilan terhadap pengasuh atau guru. Pada pesantren tradisional, pengasuh biasa dipanggil dengan gelar kiai, ajengan, datuk, atau panggilan lokal lain. Pada pesantren modern, sebagian masih memakai istilah kiai sebagian dengan kata ustadz. Sebagaimana dalam (Nasrudin, 2016: 70). Kurikulum Pendidikan, Kurikulum pesantren tradisional/salafiyah menekankan pada ilmu agama, terutama meliputi Alquran, hadits, fikih, akidah, akhlak, sejarah Islam, faraidh (ilmu waris Islam), ilmu falak, ilmu hisab, dan lain-lain. Semua materi pelajaran yang dikaji memakai buku berbahasa Arab melayu yang umum disebut dengan kitab kuning, kitab gundul, kitab klasik, atau kitab turats. Pada pengajianpengajian tertentu, kitab pedoman yang dipakai merupakan pilihan turun-temurun dan memiliki ikatan sanad dengan para guru dari pengasuh. Kitab wajib di pesantren salaf antara lain Ihya Ulumiddin (tasawuf), Shahih Bukhari dan Shahih Muslim (hadis), Tafsir Jalalain, Alfiyyah Ibnu Malik(nahwu) dengan varian syarahnya, dan lain-lain. Kitab-kitab tersebut sampai hari ini masih dikaji di pesantren Nurul Islam Seribandung.

Sedangkan pesantren modern memiliki ciri keseharian lebih disiplin. Bahkan sebagian ada yang hampir mirip militer. Sholat boleh pakai celana panjang, tidak pakai peci, Sopan santun agak berbeda dengan santri pesantren salaf. Namun bagi pesantren modern, kesopanan tersebut sudah tepat bagi mereka. Karena santri diajari untuk tidak hanya menerima informasi dan tunduk patuh, tetapi juga kritis dan disiplin serta tegas. Selanjutnya untuk pesantren modern, tergantung kemana pesantren tersebut menginduk. Jika berinduk ke pesantren Gontor, tentu tanpa berpihak pada satu golongan atau aliran. Tetapi bagi pesantren modern NU tentu akan merujuk doktrin keagamaan sama dengan pesantren salaf.

\section{Kepemimpinan Kiai Pesantren Nurul Islam Seribandung Ogan Ilir}

Pondok pesantren Nurul Islam Seribandung merupakan salah satu pondok tertua di provinsi Sumatera Selatan, karateristik dari tuanya pondok ini adalah dilihat dari struktur bangunan gedung yang sudah mulai memudar dan terlihat memang ada bangunan lama, kepemimpinan kiai di pesantren ini sedang memasuki era kelima yang dipimpin oleh kiai Syazali Tidah Anwar, alumninya sudah tersebar di mana-mana, baik di birokasi, akademisi, politikus, pengusaha, tehnokrat dan lainnya serta pesantren ini telah mengalami pasang surut dalam perkembangannya. 
Salni Fajar

Tradisi Pesantren : Antara Tradisionalis dan Modernis

\section{Tipologi Kepemimpinan Kiai Pesantren Nurul Islam Seribandung}

Paham keagamaan yang dianut di Pondok Pesantren Nurul Islam Seribandung adalah faham Ahlusunnah Waljamaah (Aswaja), yang dalam konteks ini berafiliasi dengan organisasi kemasyarakatan dan keagamaan Nandlathul Ulama (NU), yang bermazhab salah satu dari imam mazhab yang empat (Hanafi, Maliki, dan Hanbali). Namun demikian, pengasuh pesantren ini sangat toleran terhadap siapa saja. Indikatornya adalah pengasuh pesantren ini tidak pernah terlibat konflik dengan siapa pun yang berbeda faham keagamaan. Inilah kemudian yang menginspirasi setiap kebijakan yang ada di Pondok Pesantren Nurul Islam.

Setiap kepemimpinan mempunyai tipe tersendiri sesuai dengan karakter yang menjadi pemimpin dalam sebuah lembaga, baik lembaga negara, lembaga perusahaan, lembaga keuangan, dan lembaga pendidikan. Tipe kepemimpinan sendiri mempunyai banyak macam variasi: tipe kepemimpinan demokratis, tipe kepemimpinan otoriter, tipe kepemimpinan paternalistik, dan tipe kepemimpinan karismatik (Mustajab, 2015 : 134). Namun, dalam hal ini kepemimpinan yang dimaksud adalah kepemimpinan yang diterapkan di Nurul Islam adalah tipe kepemimpinan karismatik tradisionalis, seperti yang di jelaskan oleh salah seorang nara sumber berikut ini:

"Tipe kepemimpinan Kiai Syazali ialah menggunakan tipe kepemimpinan karismatik dengan tidak meninggalkan nilai-nilai tradisional dan kesederhaan, khususnya dalam pelaksanaan aktivitas pendidikan di Pondok Pesantren Nurul Islam. Tipe kepemimpinan beliau dibangun dua sistem pola hubungan baik instruktif dan koordinatif, seperti halnya ketika kiai menentukan sebuah kebijakan atau melaksanakan hasil kebijakan" (Wawancara dengan pengasuh Ponpes Nurul Islam).

Tipe kepemimpinan karismatik dengan tidak meninggalkan tradisionalnya ini Menurut Wahjosumidjo, "karisma kepemimpinan kiai terkait dengan luasnya penguasaan kajian ilmu agama pada kiai dan konsistensi pengamalan ilmu agama dalam kehidupan keseharian kiai"(Wahjoetomo, 1997: 4).

Dengan asumsi bahwa karisma dapat diidentikkan dengan power kiai, maka kepemimpinan karismatik kiai dapat pula ditelaah dengan konsep sumber kewibawaan tipe yang mempunyai arti perintah atasan kepada bawahan mengenai kinerja yang harus dilaksanakan yang berkenaan dengan perintah kinerja kepesantrenan khususnya seperti perintah pengasuh pesantren kepada pengurus pondok pesantren.

Sedangkan tipe kepemimpinan tradisional, sebagaimana diungkap dalam buku Suparno (Suparno, 2002 : 44-52) adalah pertama, Bersifat Agamis, agama dan kepercayaan adalah salah satu nilai leluhur yang diwariskan masyarakat tradisional. Maka, dalam kehidupannya sehari-hari masyarakatnya bersifat religius 
atau agamis. Semua kegiatan mereka akan dikaitkan dengan agama dan kepercayaan yang ada. Kedua, Mengutamakan kepentingan kelompok, dengan sifat homogenitas, tertutup, dan jumlah komunitas yang sedikit, masyarakat ini cenderung lebih mengutamakan kepentingan kelompoknya atau kepentingan masyarakatnya. Kepentingan pribadi pada masyarakat ini harus berdasarkan kepentingan bersama atau kelompok. Ketiga, adanya sistem pewarisan, masyarakat tradisional adalah masyarakat yang mewariskan nilai leluhur. Dalam prakteknya, tidak hanya nilai-nilai leluhur yang diwariskan turun temurun. Segala sesuatu yang mereka miliki diwariskan turun temurun, termasuk harta. Keempat, Menerapkan aturan yang ketat, tipe ini juga menerapkan aturan yang ketat bagi setiap pelanggaran nilai-nilai leluhur, norma-norma, dan tradisi yang mereka anut. Siapa saja yang melanggar aturan tersebut akan dikenai sanksi. Sanksi biasanya berupa sanksi sosial yang memiliki efek malu dan jera. Misalnya, sanksi berupa pengucilan dan pengarakan pelaku kesalahan atau pelanggaran keliling kampung. Kelima, Penggunaan Teknologi Rendah, Karena tipe tradisional menutup diri terhadap semua perubahan dan budaya asing, otomatis penggunaan teknologi dalam kehidupan sehari-hari juga sangat rendah (bukan tidak bisa). Mereka masih menggunakan alat-alat tradisional dalam melakukan kegiatan. Keterikatan dengan alam juga sangat tinggi. Keenam, Statis, masyarakat statis artinya cenderung tidak ada pergerakan ke arah yang lebih maju. Meskipiun ada, pergerakan tersebut akan berjalan sangat lambat. Hal ini disebabkan karena sifat masyarakat tradisional yang tertutup dan mobilitas rendah.

Dari tipe kepemimpinan di atas kemudian pesantren ini tetap mempertahankan tradisinya dan seluruh kegiatan tetap berjalan normal, termasuk kegiatan belajar mengajar dan tradisi muthola'ah dan muzakarah yang dilaksanakan setiap malam abis isya' sampai jam 21.00 wib. Dilanjutkan dengan pagi sebelum sekolah formal, yaitu kajian kitab kuning seperti kitab sabilul muhtadin (kitab fiqih ibadah). Kiai yang megajarnya berpakaian sarung dan keliahatn sangat sederhana, tetapi ilmu agama kiai tersebut sangat dalam, hal ini terlihat ketika kiai Rasyid yang sedang mengajarkan system muthola'ah, dan ada sesi Tanya jawab tentang fiqih ibadah.

\section{Implikasi Tipe Kepemimpinan Kiai Pesantren Nurul Islam}

\begin{tabular}{|l|l|l|}
\hline \multicolumn{1}{|c|}{ FOKUS } & \multicolumn{1}{|c|}{ KOMPONEN } & \multicolumn{1}{c|}{ TEMUAN } \\
\hline $\begin{array}{l}\text { Tradisi } \\
\text { kepemimpinan kiai } \\
\text { pesantren Nurul }\end{array}$ & $\begin{array}{l}\text { Tipe kepemimpinan } \\
\text { dalam pendidikan } \\
\text { Islam }\end{array}$ & $\begin{array}{l}\text { a. tipe kepemimpinan karismatik } \\
\text { besantren Pola intruksi dan koordinasi }\end{array}$ \\
\cline { 2 - 4 } & $\begin{array}{l}\text { Pola-pola aktivitas } \\
\text { pengarahan pondok } \\
\text { yesantren }\end{array}$ & $\begin{array}{l}\text { a. Forum-forum rapat yang berkenaan } \\
\text { dengan kepesantrenan } \\
\text { b. Pengarahan dilakukan ketika } \\
\text { memimpin pengajian kitab klasik }\end{array}$ \\
\hline
\end{tabular}


Tradisi Pesantren : Antara Tradisionalis dan Modernis

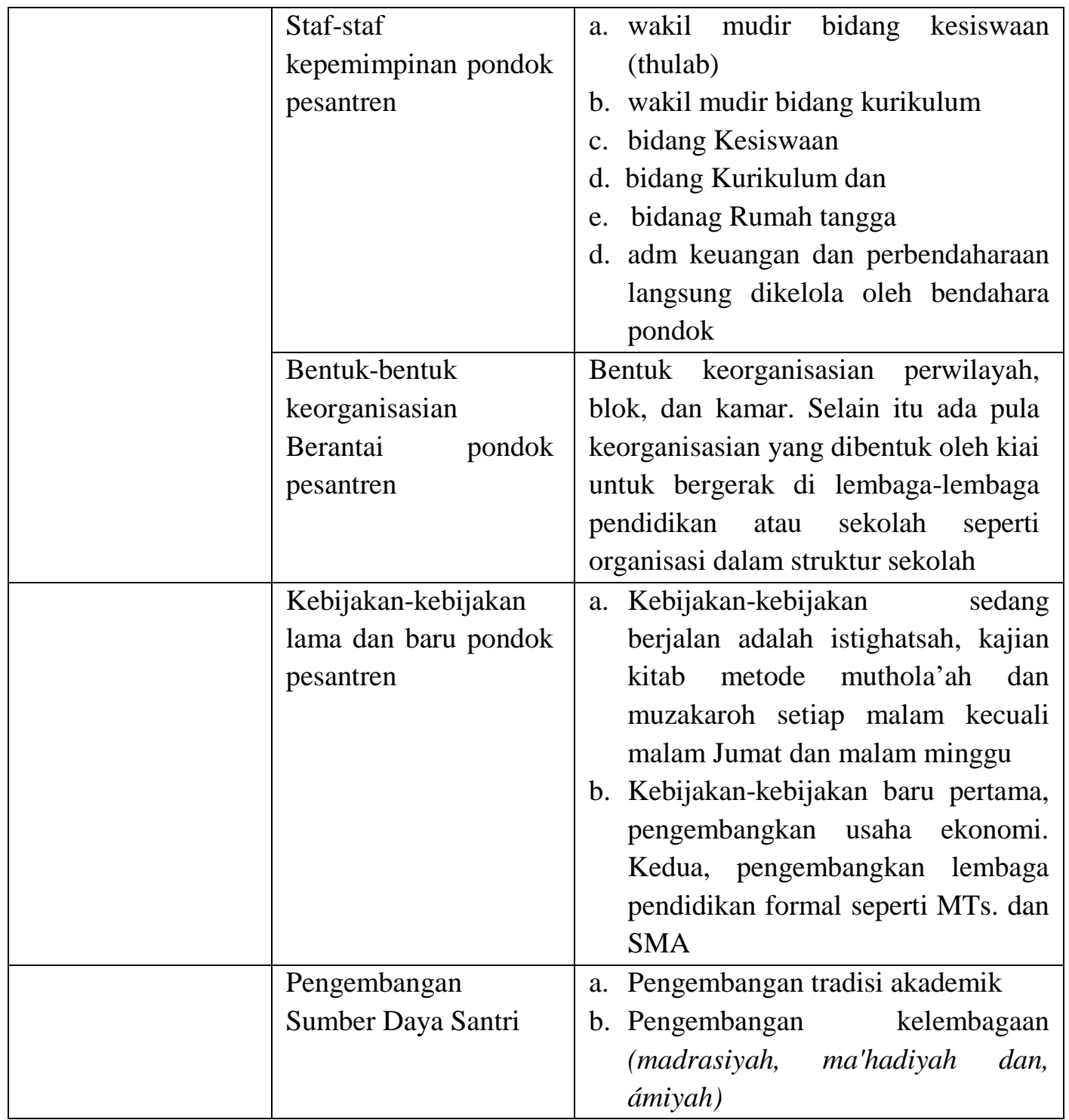

Tipe kepemimpinan yang diterapkan oleh Kiai Syazali adalah tipe kepemimpinan karismatik tradisionalis.

\section{Kepemimpinan Kiai Pesantren Raudhatul Ulum Sakatiga}

Pondok pesantren Raudhatul Ulum yang dulu dikenal pondok "PIRUS" juga merupakan salah satu pondok tertua di Provinsi Sumatera Selatan karena dilihat dari cikal bakal pondok ini yaitu mulai dari tahun 1930. Selanjutnya mengalami pasang surut dalam pengembangannya dan juga kepemimpinannya, karena suatu pesantren akan menjadi faktor utama dari kepiawaian seorang pemimpin. Raudhatul Ulum sudah merubah dirinya menjadi tradisi yang tradisional menjadi modernis. 
Tradisi Pesantren : Antara Tradisionalis dan Modernis

\section{Tipelogi Kepemimpinan Kiai Pesantren Raudhatul Ulum}

Pondok pesantren Raudhatul Ulum yang dulu dikenal pondok "PIRUS" juga merupakan salah satu pondok tertua di Provinsi Sumatera Selatan karena dilihat dari cikal bakal pondok ini yaitu mulai dari tahun 1930. Selanjutnya mengalami pasang surut dalam pengembangannya dan juga kepemimpinannya, karena suatu pesantren akan menjadi faktor utama dari kepiawaian seorang pemimpin. Raudhatul Ulum sudah merubah dirinya menjadi tradisi yang tradisional menjadi modernis.

Di samping itu, pemimpin pesantren setidaknya membutuhkan dua kriteria agar fungsi pesantren berjalan secara maksimal. Dua kriteria itu adalah pertama, kapasitas keilmuan dan dedikasi tinggi pada masyarakat yang menjadi objek dakwahnya. Kapasitas keilmuan yang memadai penting dimiliki oleh pemimpin pesantren karena tugas yang ia emban tidak mungkin dilaksanakan tanpa kapasitas ilmiah yang memadai. Kedua, pemimpin pesantren haruslah seseorang yang memiliki kemampuan mengkomunikasikan nilai-nilai Islam kepada masyarakat, di samping dedikasi tinggi untuk mengislamkan masyarakat dalam maknanya yang paling luas.

Tradisi pergantian kepemimpinan di Raudhatul Ulum tidak berdasarkan garis keturunan langsung. Disini bila kita menilik bahwa fungsi utama pesantren adalah lembaga transmisi nilai-nilai Islam di masyarakat, maka pemimpin pesantren haruslah dipilih berdasar kompetensi keilmuannya dan dedikasinya pada masyarakat. Berkaitan dengan hal tersebut, dalam pergantian kepemimpinan, selama pesantren ini ada pemimpin itu satu dusun dan memang dianggap mampu untuk memimpin, serta peluangnya untuk memimpin, maka diberikan kesempatan untuk memimpin. Kiai Tol'at adalah putra daerah asli Sakatiga yang merantau belajar di Gontor dan di Madinah, saat beliau bekerja di kedutaan Saudi, dipanggil oleh tokoh-tokoh masyarakat Sakatiga untuk pulang dan mengembangkan pondok yang saat itu pesantren sedang mati suri. Berkaitan dengan hal tersebu.

Awalnya corak kepemimpinan yang diterapkan dengan sistem kekeluargaan, yaitu bersama-sama untuk mengelola pesantren ini, lebih lanjut dalam hal kepengurusan, pesantren Raudhatul Ulum Sakatiga menerapkan kepemimpinan rasionality. Ini menjadi bukti bahwa dalam kepemimpinan telah terjadi pengembangan dan kepemimpinan yang awalnya individu beralih pada tipe kepemimpinan rasional modernis.

Dari situ dapat diketahui bahwa tipe kepemimpinan yang diterapkan di Pesantren Raudhatul Ulum Sakatiga sangat mengutamakan skill, integritas dan loyalitas, hal ini terlihat dari penunjukan pengelola-pengelola pesantren dari wakil mudir, asisten-asisten mudir dan kepala-kepala bidang, ada tiga orang yang asli Sakatiga dan ada hubungan keluarga dengan kiai Tol'at. Karena tipe 
kepemimpinan rasional ini akan berimplikasi kepada kelancaran penerapan program-program pesantren.

Setiap kepemimpinan mempunyai tipe tersendiri sesuai dengan karakter yang menjadi pemimpin dalam sebuah lembaga, baik lembaga negara, lembaga perusahaan, lembaga keuangan, dan lembaga pendidikan. Tipe kepemimpinan sendiri mempunyai banyak macam variasi: model kepemimpinan demokratis, model kepemimpinan otoriter, model kepemimpinan paternalistik, dan model kepemimpinan karismatik. Namun, dalam hal ini kepemimpinan yang dimaksud adalah kepemimpinan yang diterapkan di Pesantren Raudhatul Ulum, khususnya yang menjadi pembahasan adalah tipe kepemimpinan yang diterapkan oleh $\mathrm{KH}$ Tol'at Wafa Ahmad, Lc adalah tipe kepemimpinan rasional modernis, seperti yang di jelaskan oleh salah seorang nara sumber berikut ini:

"Tipe kepemimpinan Kiai Tol'at ialah menggunakan tipe rasional yang dalam implementasinya sudah mengarah modern, khususnya dalam pelaksanaan manajemen pesantren, aktivitas pendidikan, Sumber Daya Manusia di Pondok Pesantren Raudhatul Ulum. Tipe kepemimpinan beliau dibangun dua sistem pola hubungan baik instruktif dan koordinatif, seperti halnya ketika kiai menentukan sebuah kebijakan atau melaksanakan hasil kebijakan"(Wawancara dengan pengasuh Ponpes Raudhatul Ulum pada tanggal 24 Desemver 2017).

Tipe kepemimpinan rasional modernis sendiri adalah tipe yang mempunyai arti penunjukan dan pengangkatan staf-staf pesantren dengan rasional dan sesuai kapabilitas dan skill, serta dalam membuat kebijakan selalu ada dasar dan visi ke depan yang jauh. Dalam menerapkan tipe ini kiai selalu koordinatif yang mana pola hubungan bawahan dengan atasan yang termanivetasi dalam menyampaikan ide dan gagasan yang berhubungan dengan kinerja, khususnya gagasan pengurus yang berkaitan dengan kinerja di Pondok Pesantren Raudhatul Ulum, seperti yang di jelaskan oleh Ustad M. Syafiq dibawah ini:

"Kiai dalam kepemimpinannya sangat rasional terkadang dia memberikan intruksi langsung kepada bawahannya (pengurus), selain itu Kiai Tol'at menerima ide-ide dan gagasan bawahannya dalam mengembangkan pondok pesantren, salah satu contoh yang paling nyata adalah ketika kiai mempunyai ide-ide yang berkaitan dengan pondok pesantren, kiai memanggil wakil mudir untuk menyampaikan intruksi yang kemudian untuk di musyawarahkan dengan pengurus yang lainnya. Selain itu, kiai juga mengkomodir ide-ide yang disampaikan oleh bawahannya melalui hasil musyawarah mufakat, sehingga setiap kebijakan Pondok Pesantren Raudhatul Ulum tidak semua dari atas atau dari Kiai Tol'at, namun kiai juga dalam mengambil kebijakan memberi ruang pada bawahannya untuk memberikan ide dan gagasan dalam

Tersedia Online di http://jurnal.radenfatah.ac.id/index.php/medinate 
memajukan pondok pesantren"(Wawancara dengan ust. M. Syafiq (asisten Mudir) pada tanggal 15 Desember 2017).

Dari tipe kepemimpinan kepemimpinan kiai di atas kemudian berkembang dan bertransformasi ke dalam pola-pola kepemimpinan sebagaimana uraian berikut:

Implikasi Tipe Kepemimpinan Kiai Pesantren Raudhatul Ulum

\begin{tabular}{|c|c|c|}
\hline FOKUS & KOMPONEN & TEMUAN \\
\hline \multirow{7}{*}{$\begin{array}{l}\text { Tradisi } \\
\text { kepemimpinan } \\
\text { Kiai pesantren } \\
\text { Raudhatul } \\
\text { Ulum yang } \\
\text { modernis }\end{array}$} & $\begin{array}{l}\text { Tipe kepemimpinan } \\
\text { dalam pendidikan } \\
\text { pesantren }\end{array}$ & $\begin{array}{l}\text { a. tipe kepemimpinan Rasional } \\
\text { modernis } \\
\text { b. pada saat-saat tertentu kiai mengguna } \\
\text { pola intruksi dan koordinasi }\end{array}$ \\
\hline & $\begin{array}{l}\text { Pola-pola aktivitas } \\
\text { pengarahan pondok } \\
\text { pesantren }\end{array}$ & $\begin{array}{l}\text { a. Forum-forum rapat yang berkenaan } \\
\text { dengan kepesantrenan } \\
\text { b. Pengarahan kepada santri/wati } \\
\text { dilakukan ketika akhir sanah, atau } \\
\text { aksedentil memimpin rapat bagi } \\
\text { pengurus pesantren }\end{array}$ \\
\hline & $\begin{array}{l}\text { Staf-staf } \\
\text { kepemimpinan } \\
\text { pondok pesantren }\end{array}$ & $\begin{array}{l}\text { a. Protokol Kiai (mudir) Sekretaris } \\
\text { pribadi } \\
\text { b. Wakil Mudir } \\
\text { c. Assiten Mudir, bidang informasi dan } \\
\text { humas, Rumah tangga dan keluarga, } \\
\text { keuangan, BUMP, akademik dan } \\
\text { kesiswaan. } \\
\text { c. Staf masing-masing bidang }\end{array}$ \\
\hline & $\begin{array}{l}\text { Bentuk-bentuk } \\
\text { keorganisasian } \\
\text { Berantai pondok } \\
\text { pesantren }\end{array}$ & $\begin{array}{l}\text { Bentuk keorganisasian perbidang kerja. } \\
\text { Selain itu ada pula keorganisasian yang } \\
\text { dibentuk oleh kiai untuk bergerak di } \\
\text { lembaga pendidikan tinggi (STITRU) }\end{array}$ \\
\hline & $\begin{array}{l}\text { Pengembangan } \\
\text { Sumber Daya Santri }\end{array}$ & $\begin{array}{l}\text { a. Pengembangan admistrasi pesantren } \\
\text { dan tradisi belajar mengajar } \\
\text { (akademik) } \\
\text { b. Pengembangan kelembagaan } \\
\text { (madrasiyah dan ma'hadiyah, } \\
\text { 'amiyah) }\end{array}$ \\
\hline & Kiai berpolitik & $\begin{array}{l}\text { a. aktif di partai politik (PKS) } \\
\text { b.Menjadi Ketua Majelis Pertimbangan } \\
\quad \text { Partai (PKS) Sumsel) }\end{array}$ \\
\hline & $\begin{array}{l}\text { Kaderisasi Pemimpin } \\
\text { pesantren }\end{array}$ & $\begin{array}{l}\text { a. sudah menyiapkan anak sulung kiai } \\
\text { b. sekarang yang memegang jabatan- } \\
\text { jabatan penting bukan dari keluarga } \\
\text { kiai,.tapi mereka mempunyai skill, }\end{array}$ \\
\hline
\end{tabular}


\begin{tabular}{|l|l|}
\hline & integritas dan loyalitas \\
\hline
\end{tabular}

Tipe kepemimpinan yang diterapkan oleh Kiai Tol'at adalah tipe kepemimpinan Rasional Modernis dengan waktu-waktu tertentu memakai pola instruktif dan koordinatif.

\section{Kesimpulan}

Tipe kepemimpinan kiai Pondok Pesantren Nurul Islam menggunakan tipe kepemimpinan karismatik tradisionalis yaitu pesantren Nurul Islam Seribandung tetap eksis dan konsisten dengan tradisi pesantren, tidak berubah dan tidak menghilangkan ruh pesantren. Yang dimaksud eksis di sini hasil pengamatan penulis yaitu implementasi belajar mengajar (metode Muthola'ah dan Muzakaroh), sangat erat pengelola pesantren dari keluarga dan keturunan kiai, kurikulumnya dari pesantren Darussalam Labuhan Haji Aceh Selatan, pimpinan pesantren tipe karismatik tradisionalis terlihat dari pembelajaran ektrakulikuler dan cara memenej pesantren, tipe kiai karismatik tradisonalis ini tidak serta merta meninggalkan manajemen pengelolaan pesantren yang baik dan terukur. Dalam realitanya Kiai juga pada saat-saat tertentu menerapkan pola instruktif dan koordinatif. Pola instruksi adalah sebuah pola yang mempunyai arti perintah atasan kepada bawahan mengenai kinerja yang dilaksanakan yang berkenaan dengan perintah kinerja kepesantrenan, seperti perintah kiai kepada pengurus pondok pesantren. Sedangkan pola koordinatif adalah pola hubungan bawahan dengan atasan yang termanivestasi dalam bentuk komunikasi antara atasan dan bawahan dalam menyampaikan ide dan gagasan yang berhubungan dengan kinerja, khususnya mengenai ide dan gagasan pengurus terkait kinerja di Pondok Pesantren Nurul Islam.

Sedangkan tipe kepemimpinan yang diterapkan oleh kiai Tol'at adalah tipe kepemimpinan rasional modernis dengan dengan pola instruktif dan koordinatif. Tipe pemimpin rasional modernis adalah sebuah tipe yang menurut pikiran dan pertimbangan yang logis atau menurut pikiran yang sehat atau cocok dengan akal. sehingga pendekatan dengan ukuran ini sering menganggap bahwa pikiran dan akal merupakan satu-satunya dasar untuk memecahkan problem (kebenaran) yang lepas dari jangkauan indra atau paham yang lebih mengutamakan (kemampuan) akal daripada batin dan rasa. secara mudah sering di sebut empiris, logika berdasarkan nalar yang dalam arti adanya sesuatu kejadian yang bisa di terima oleh akal dan mampu di pahami oleh bathin dan rasa. Sedangkan modernis merupakan imlepelemntasi dari sebuah pikiran yang tidak jumud dan aktual sebagaimana teori yang telah disampaikan, dalam pesantren perbedaan yang mencolok adalah dalam panggilan di pesantren tradisional pengasuh biasa dipanggil dengan gelar kiai, ajengan, datuk, atau panggilan lokal lain. Pada 
pesantren modern, sebagian masih memakai istilah kiai sebagian dengan kata ustadz, pimpinan pesantren Raudhatul Ulum KH. Tol'at Wafa para guru dan santri, masih memanggil beliau dengan panggilan ustadz.

Pada waktu-waktu tertentu kiai menggunakan pola intruksi yang ada di Pondok Pesantren Raudhatul Ulum adalah sebuah pola yang mempunyai arti perintah atasan (kiai) kepada bawahan (pengurus/santri) mengenai kinerja yang harus dilaksanakan yang dalam hal ini berkenaan dengan perintah kinerja kepesantrenan khususnya seperti perintah kiai kepada pengurus pondok pesantren.

\section{Daftar Pustaka}

Dhofier, Zamakhsyari, Tradisi Pesantren Studi Pandangan Hidup Kyai dan Visinya Mengenai Masa Depan Indonesia, Jakarta: LP3ES, 2011.

Hasbullah, Sejarah Pendidikan Islam di Indonesia: Lintasan Sejarah Pertumbuhan dan Perkembangan, Jakarta: PT. Raja Grafindo Persada, 1999.

Ismail (Ed). Dinamika Pesantren dan Madrasah Yogyakarta: Pustaka Pelajar Offset, 2002.

Kartono, Kartini, Pemimpin dan Kepemimpinan, Jakarta: PT. Raja Grafindo Persada, 1998.

Muhaimin, Wacana Pengembangan Pendidikan Islam, Surabaya: Pelajar Pustaka, 2004.

Muhaimin, Nuansa Baru Pendidikan Islam; Mengurai Benang Kusut Pendidikan, Jakarta: Raja Grafindo, 2006.

Mastuhu., Dinamika Sistem Pendidikan Pesantren: Suatu Kajian tentang Unsur dan Nilai Sistem Pendidikan Pesantren, Jakarta: INIS, 1994.

Mustajab., Masa Depan Pesantren Telaah atas Model Kepemimpinan dan Manajemen Pesantren Salaf, Yogyakarta: LKIS, 2015.

Muhaimin, Wacana Pengembangan Pendidikan Islam, Yogyakarta: Pustaka Pelajar, 2004.

Nasir, M.R., Mencari Tipologi Format Pendidikan Ideal: Pondok Pesantren di Tengah Arus Perubahan, Yogyakarta: Pustaka Pelajar, 2005.

Nata, Abuddin., Sosiologi Pendidikan Islam, Jakarta: RajaGrafindo Persada, 2014.

Nawawi, Hadari. Kepemimpinan Menurut Islam, Yogyakarta: Gajah Mada

Tersedia Online di http://jurnal.radenfatah.ac.id/index.php/medinate 
Universiti Press, 1993.

Nasir, Ridwan Mencari Tipologi Format Pendidikan Ideal Pondok Pesantren di Tengah Arus Perubahan, Yogyakarta: Pustaka Pelajar, 2010.

Sina, Ibn., "Model Gaya Kepemimpinan Situasional", dalam Edukasi, Vol. 7 No. 2, September 2012.

Sugiyono, Memahami Penelitian Kualitatif; Dilengkapi Contoh Proposal dan Laporan Penelitian, Bandung: Alfabeta, 2005.

Wahid, Abdurrahman Beberapa Pemikiran tentang Kepemimpinan dalam Pengembangan Pesantren, Naskah ceramah disampaikan pada latihan Tenaga Pembimbing Pondok Pesantren yang diselenggarakan Departemen Agama RI di Cibubur Jakarta pada 2-12 Oktober 1978.

Wahab, Abdul Menulis Karya Ilmiah, Surabaya: Airlangga University Press, 1999.

Wahjoetomo, Perguruan Tinggi Pesantren, Jakarta: Gema Insani Press, 1997.

Ziemek, Manfred Pesantren dalam Perubahan Sosial, Jakarta: P3M, 1986.

Tersedia Online di http://jurnal.radenfatah.ac.id/index.php/medinate 